\title{
Genetic Data Showing Evolutionary Links between Leishmania and Endotrypanum
}

\author{
Elisa Cupolillo/ ${ }^{+}$, Luiza OR Pereira, Octávio Fernandes*, Marcos P Catanho*, \\ Júlio C Pereira**, Enrique Medina-Acosta**, Gabriel Grimaldi Jr
}

\author{
Laboratório de Leishmaniose, Departamento de Imunologia *Departamento de Medicina Tropical, Instituto \\ Oswaldo Cruz, Av. Brasil 4365, 21045-900 Rio de Janeiro, RJ, Brasil **Laboratório de Biotecnologia, \\ Universidade Estadual do Norte Fluminense, 28015-620 Campos, RJ, Brasil
}

\begin{abstract}
Striking similarities at the morphological, molecular and biological levels exist between many trypanosomatids isolated from sylvatic insects and/or vertebrate reservoir hosts that make the identification of medically important parasites demanding. Some molecular data have pointed to the relationship between some Leishmania species and Endotrypanum, which has an important epidemiological significance and can be helpful to understand the evolution of those parasites. In this study, we have demonstrated a close genetic relationship between Endotrypanum and two new leishmanial species, L. (V.) colombiensis and L. (V.) equatorensis. We have used (a) numerical zymotaxonomy and $(b)$ the variability of the internal transcribed spacers of the rRNA genes to examine relationships in this group. The evolutionary trees obtained revealed high genetic similarity between L. (V.) colombiensis, L. (V.) equatorensis and Endotrypanum, forming a tight cluster of parasites. Based on further results of (c) minicircle kDNA heterogeneity analysis and (d) measurement of the sialidase activity these parasites were also grouped together.
\end{abstract}

Key words: Leishmania colombiensis - Leishmania equatorensis - Endotrypanum - multilocus enzyme electrophoresis - molecular characterization - numerical analysis - sialidase activity - kDNA

Parasitic protozoa of the genus Leishmania (Kinetoplastida: Trypanosomatidae) are biologically diverse group of microorganisms. Taxonomic studies of leishmanial isolates from the New World indicate tremendous diversity within this genus (Cupolillo et al. 1995). A number of new Leishmania species from sylvan areas of the Neotropics are associated with disease in humans; others appear to be restricted to lower orders of mammals, such as rodents and edentates (Grimaldi et al. 1989).

Sloths are reservoir hosts of at least five named Leishmania species of the subgenus Viannia $[L$. guyanensis Floch, 1954; L. panamensis Lainson \& Shaw 1972; L. shawi Lainson et al. 1989; L. colombiensis Kreutzer et al. 1991 and $L$. equatorensis Grimaldi et al. 1992], responsible for

\footnotetext{
This work was supported by grants of the Instituto Oswaldo Cruz-Fiocruz, FAPERJ and CNPq to EC, OF and GG Jr. Research work at the Laboratório de Biotecnologia-UENF is supported by grants from FENORTE, FINEP, FAPERJ and WHO/TDR to EM-A. ${ }^{+}$Corresponding author. Fax: +55-21-280.1589. E-mail: ecupoli@gene.dbbm.fiocruz.br

Received 15 June 1998

Accepted 30 July 1998
}

human cutaneous and/or mucosal leishmaniasis (Grimaldi \& Tesh 1993). Infections with other biologically distinct groups of trypanosomatid protozoa, such as Endotrypanum and Trypanosoma are also found in sloths (Deane 1961, Pipkin 1968, Travi et al. 1989, Shaw 1992).

In nature, all Leishmania spp. are transmitted by the bite of infected phlebotomine sand flies (Diptera:Psychodidae). However, many flagellates other than Leishmania commonly are found in sand flies in Neotropical forests. Arias et al. (1985) identified E. schaudinni and other Endotrypanum sp. infections in sand flies and sloths captured in the Amazon Region of Brazil. Results of kinetoplast DNA probe identifications of promastigotes present in sand flies captured near Manaus, Brazil also demonstrated Endotrypanum infections in $L u$. shannoni, as well as in $L u$. umbratilis and $L u$. anduzei (Rogers et al. 1988). Further evidence for the development of Endotrypanum in phlebotomines was obtained by feeding several laboratory-reared sand fly species on infected sloths (Christensen and Herrer 1976, 1979, Shaw 1981).

Endotrypanum spp. are digenetic trypanosomatids in that they are intraerythrocytic parasites of sloths and are transmitted by phlebotomine sand flies (Shaw 1992). Endotrypanum shares many other charecteristics with Leishmania. Cul- 
tured-derived promastigotes of parasites in both genera are morphologically similar. Studies employing monoclonal antibodies for the analysis of the genus Endotrypanum have shown antigenic similarites between these parasites and some Leishmania species (Franco et al. 1997). Furthemore, molecular trees clustered the sandfly-borne digenetic parasites Leishmania and Endotrypanum together, sharing a common ancestor and representing a relatively recent lineage from the Trypanosomatidae family (Fernandes et al. 1993). Results of hybridization using kDNA probes (Pacheco et al. 1990) support the view that Endotrypanum and the peripylarian leishmanial parasites of the subgenus Viannia Lainson \& Shaw 1987 are phylogenetically close (Shaw 1992). In addition, phylogenetic studies have demonstrated that the most divergent Leishmania species are $L$. (L.) hertigi and $L$. (L.) herreri, claimed to be closer to Endotrypanum than to the other Leishmania (Croan \& Ellis 1996, Noyes et al. 1996, 1997, Croan et al. 1997).

In this study, we have shown evolutionary links between Endotrypanum and some leishmanial parasites based on their molecular genetics, as characterized using a broad assemblage of methodologies. The data presented here demonstrate that E. schaudinni, L. (V.) colombiensis and $L$. (V.). equatorensis form a tight phylogenetic cluster, an evolutionary linked group that should be explored to understand the origin(s) of neotropical pathogenic Leishmania.

\section{MATERIALS AND METHODS}

Parasites - Leishmania and Endotrypanum (Table I) were cultured in Scheneider's Drosophila medium (Gibco, Grand Island, NY) supplemented with $10 \%$ heat-inactivated FBS (Biolab, Rio de Janeiro, Brazil) at $24^{\circ} \mathrm{C}$. In the preparation of samples, the parasite (promastigotes in the late phase of growth cultures) were harvested by centrifugation $\left(3,800 \mathrm{xg}\right.$ for $15 \mathrm{~min}$ at $\left.4^{\circ} \mathrm{C}\right)$ and washed twice in saline $\mathrm{pH} 8.0$, containing the appropriate buffer.

Biochemical/Molecular characterization - The procedures used for characterizing the parasites (multilocus enzyme electrophoresis - MLEE, measurement of the sialidase activity, PCR amplification and restriction enzyme digestion of the parasite ITSrRNA, cloning and sequencing of the conserved region of the minicircle kDNA molecules) have been described in detail in previous publications (Cupolillo et al. 1994, 1995, Medina-Acosta et al. 1994, Fernandes et al. 1996). Sialidase activity was measured using a single-cell HITACHI F4500 spectrofluorometer $(350 \mathrm{~nm}$ excitation and $460 \mathrm{~nm}$ emission wavelengths). The sequencing was performed in automatic sequencing (AbiPrisma, Applied Biosystem).

Numerical analysis - The MLEE data was analyzed by phenetic methods using the NTSYS software program (version 1.7, exeter software). Principal coordinate analysis was performed based on Euclidian distance between the samples. The similarity level between the Leishmania species and Endotrypanum was calculated using the Jaccard's coefficient. The kDNA sequences of the parasites were analyzed using the MEGA program (Kumar et al. 1993). The number of differences between the sequences were calculated and a similarity tree constructed by the Neighbor-Joining method. Bootstrap analysis was based on 500 replicates.

\section{RESULTS AND DISCUSSION}

Leishmania and Endotrypanum are very close protozoan parasites (Fernandes et al. 1993) commonly found in the same vertebrate and insect hosts. Recents studies have showing the relationship between Endotrypanum and some New World Leishmania species, mainly those from $L$. (L.) hertigi and $L$. (L.) herreri complex (Croan \& Ellis 1996, Noyes et al. 1996, 1997, Croan et al. 1997). Moreover, DNA analysis of phylogenetically informative RNA polymerase II gene of $L$. (V.) equatorensis and Endotrypanum demonstrated sequence similarities among these parasites (JJ Shaw, pers. commun.). Similarly, it appears that a close antigenic links may exist between $L$. (V.) colombiensis, L. (V.) equatorensis and Endotrypanum (Franco et al. 1997, Grimaldi et al. 1992).

Leishmania (V.) colombiensis was found infecting humans, sloths (Choloepus hoffmanni), sandflies (Lu. hartmani and Lu. gomezi), and dogs in Colombia, Panama, and Venezuela (Kreutzer et al. 1991, Delgado et al. 1993, unpublished data). L. (V.) equatorensis is an enigmatic parasite, which was isolated from the viscera of a sloth $(C$. hoffmanni) and a squirrel (Sciurus granatensis), captured in humid tropical forest on the Pacific Coast of Ecuador. Data based on biological and molecular criteria, as well as numerical zymotaxonomy analysis indicated that both these parasites are clearly distinguishable from all other known species, but clustered within the $L$. (V.) braziliensis complex (Kreutzer et al. 1991, Grimaldi et al. 1992). Multilocus enzyme electrophoresis data and the restriction fragments of the internal transcribed spacers of the rRNA gene (Cupolillo et al. 1995, 1997) have indicated a close relationship between $L$. (V.) equatorensis and $L$. (V.) colombiensis, as previously demonstrated (Kreutzer et al. 1991, Grimaldi et al. 1992). In order to better understand their taxonomic position in the genus, especially in relation to the discrimi- 
TABLE I

Origin and Identification of Leishmania and Endotrypanum strains used in this study

\begin{tabular}{llll}
\hline Stock number & Designation $^{a}$ & Species & Geographic origin \\
\hline L565 & MHOM/BR/75/M4147 & L. guyanensis & Brazil, Pará \\
L566 & MHOM/BR/O0/M2903 & L. braziliensis & Brazil, Pará \\
L575 & IFLA/BR/67/PH8 & L. amazonensis & Brazil, Pará \\
L579 & MHOM/BR/74/PP75 & L. chagasi & Brazil, Bahia \\
L888 & MCHO/EC/82/Lsp1 ${ }^{\text {a }}$ & L. equatorensis & Ecuador, Guayas \\
L889 & MSCI/EC/82/Lsp2 & L. equatorensis & Ecuador, Guayas \\
L1023 & MHOM/BR/81/M6426 & L. lainsoni & Brazil, Pará \\
L1245 & IGOM/PA/85/E582.34 & L. colombiensis & Panama, Colon \\
L1246 & IPAN/PA/85/E696.26 & L. colombiensis & Panama, Colon \\
L1247 & IGOM/PA/85/E582.36 & L. colombiensis & Panama, Colon \\
L1545 & MHOM/BR/84/M8408 & L. shawi & Brazil, Pará \\
L1365 & MDAS/BR/79/M5533 & L. naiffi & Brazil, Pará \\
E14 & MCHO/BR/80/M6159b & E. schaudinni & Brazil, Pará \\
\hline
\end{tabular}

a: host $\left[\mathrm{M}=\right.$ Mammalia: $\mathrm{CHO}=$ Choloepus sp. $\left({ }^{\mathrm{a}}\right.$ C. hoffmanni, ${ }^{\mathrm{b}}$ C. didactylus $), \mathrm{DAS}=$ Dasypus novemcinctus, HOM=Homo sapiens, SCI=Sciurus granatensis; I=Insecta: FLA=Lutzomyia flaviscultelata, GOM=Lu. gomezi, $\mathrm{PAN}=$ Lu. panamensis]/country of origin/year of isolation/original code.

nation of Leishmania from Endotrypanum and evolutive studies we decided to analyze the genetic similarity among these parasites, using several biochemical and molecular methods. This information will help define the fundamental mechanisms involved in species identification and taxonomic divergence among these microorganism.

The sialidase (EC 3.2.1.18) activity alone has been shown to be a good marker to discriminate between morphologically indistinguishable flagellates isolated from human, insects and sylvatic vertebrate reservoir hosts, such as Leishmania and Endotrypanum (Medina-Acosta et al. 1994). The general concensus is that Endotrypanum reference stocks express clear-cut varying levels of sialidase activities whereas the Leishmania reference stocks do not. In this study, we measured the sialidase activity for several neotropical Leishmania species and for reference strain E. schaudinni. As expected, Endotrypanum exhibited high levels of sialidase activity, whilst the taxonomically unquestionable Leishmania stocks (i.e., L. chagasi) were negative for this activity. However, high levels of sialidase activity were consistently obtained from both cell lysates and culture supernatants of $L$. (V.) colombiensis and $L$. (V.) equatorensis, levels comparable with those obtained for E. schaudinni (this work) and those of Trypanosoma rangeli and Trypanosoma leeuwenhoeki (Medina-Acosta et al. 1994).

Further, MLEE analyses demonstrated that $L$. (V.) colombiensis and $L$. (V.) equatorensis share alleles with Endotrypanum for some loci, such as G6PDH and IDHNAD, that were previously ad- mitted as monomorphic for the latter genus and as discriminative characters between Leishmania and Endotrypanum (Franco et al. 1996). Moreover, for the malic enzyme were found two distinct loci (ME1 and ME2) for $L$. (V.) equatorensis and $L$. (V.) colombiensis, as described for Endotrypanum but in contrast to other leishmanial parasites (Cupolillo et al. 1994, Franco et al. 1996). According to the phenetic analyses, the results showed a high level of similarity between the two Leishmania species, as well as a close relationship between this group and Endotrypanum (Fig. 1, Table II). The later parasite is genetically closest to $L$. (V.) colombiensis rather than to $L$. (V.) equatorensis (Table II). In addition, the clusters L. braziliensis/ L. naiffi and L. guyanensis/L. shawi were observed, as already demonstrated (Cupolillo et al. 1994, 1997) and L. lainsoni made a link between $L$. (V.) colombiensis/L. (V.) equatorensis/E. schaudinni and the Leishmania (Viannia) species.

The Neighbor-Joining tree constructed based on kDNA sequence data using the number of differences between Leishmania and Endotrypanum shows similar clustering of MLEE for $L$. (V.) equatorensis/L. (V.) colombiensis/E. schaudinni (Fig. 2). The position of $L$. lainsoni was maintained, forming a link between the group $L$. (V.) equatorensis/L. (V.) colombiensis/E. schaudinni and other Leishmania species. Leishmania (V.) lainsoni represents a very divergent monophyletic Viannia species, which was clustered as an independent complex (Thomaz-Soccol et al. 1993, Cupolillo et al. 1994, Fernandes et al. 1995, Eresh et al. 1995). 


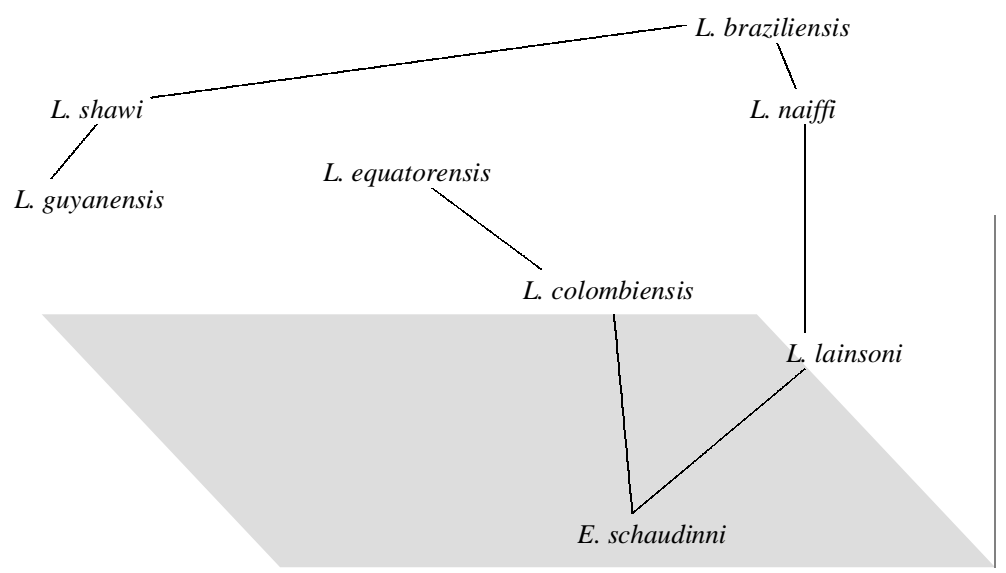

Fig. 1: principal coordinate analysis of the multilocus enzyme electrophoresis data. The three principal coordinates were claculated by Euclidian distance and plotted in 3D scale (the three principal coordinates represent $67.51 \%$ of the total variance). A minimum spanning tree was superimposed on the ordinations.

TABLE II

Similarity level among Leishmania and Endotrypanum species calculated by the Jaccard's coefficient

\begin{tabular}{|c|c|c|c|c|c|c|c|c|}
\hline & 1 & 2 & 3 & 4 & 5 & 6 & 7 & 8 \\
\hline 1. L. braziliensis & - & & & & & & & \\
\hline 2. L. guyanensis & 0.21 & - & & & & & & \\
\hline 3. L. lainsoni & 0.22 & 0.16 & - & & & & & \\
\hline 4. L. equatorensis & 0.13 & 0.08 & 0.11 & - & & & & \\
\hline 5. L. colombiensis & 0.16 & 0.07 & 0.14 & 0.40 & - & & & \\
\hline 6. E. schaudinni & 0.10 & 0.13 & 0.08 & 0.18 & 0.23 & - & & \\
\hline 7. L. shawi & 0.24 & 0.59 & 0.13 & 0.07 & 0.05 & 0.07 & - & \\
\hline 8. L. naiffi & 0.47 & 0.15 & 0.26 & 0.12 & 0.18 & 0.12 & 0.20 & - \\
\hline
\end{tabular}

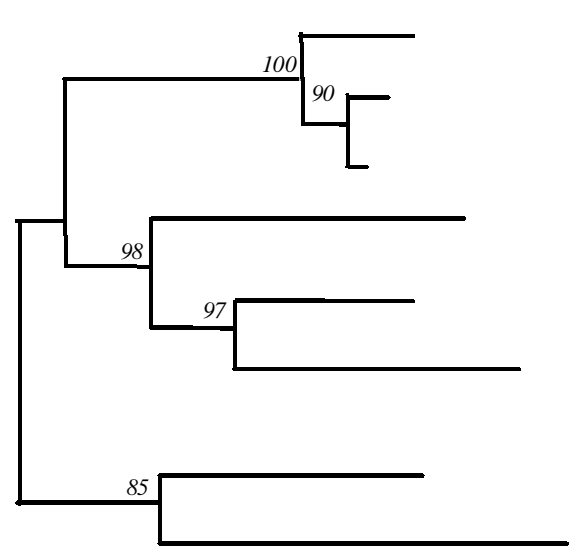

Endotrypanum schaudinii

L. equatorensis

L. colombiensis

L. lainsoni

L. braziliensis

Viannia

subgenus

L. shawi

L.chagasi

L. amazonensis

Leishmani

subgenus

$\overline{0.01}$

Fig. 2: phenetic analyze of sequences ( $83 \mathrm{bp})$ of conserved region of kDNA minicircle. The similarities were evaluated by the number of differences among the sequences and the similarity tree constructed by the Neighbor-joining method. Italic numbers represent bootstrap values based on 500 replicates. 
The internal transcribed spacers of the rRNA gene were amplified by PCR and the product digested with several restriction enzymes (Cupolillo et al. 1995). The RFLP profiles show a close but not identical pattern between $L$. (V.) colombiensis and $L .(V$.$) equatorensis. However, through this$ method Endotrypanum can be easily discriminated from the former parasites and other Leishmania species by most of the restriction enzyme profiles (Fig. 3).

The genetic similarity between Endotrypanum and New World Leishmania was also demonstrated by sequencing comparisons of the small subunit of ribosomal RNA and RNA Polymerase II genes (Croan \& Ellis 1996, Noyes et al. 1996, 1997, Croan et al. 1997). The results show that $L$. (L.) herreri (Zeledon et al. 1975), a sloth parasite, is closer to Endotrypanum than to other Leishmania species. Leishmania (L.) hertigi/L. (L.) deanei (Herrer 1971, Lainson \& Shaw 1977), which were isolates from rodents, are also genetically closest to the Endotrypanum/L. (L.) herreri group (Croan et al. 1997, Noyes et al. 1997). Some authors suggest that $L$. (L.) herreri is a misclassified parasite and therefore probably represents Endotrypanum (Croan \& Ellis 1996). Although L. (L.) hertigi and $L$. (L.) deanei are still enigmatic parasites (Lainson 1997) there are evidences supporting their classification as Leishmania. An interesting aspect is that these Leishmania species and Endotrypanum are biologically distinct parasites and do not share the same hosts.

In contrast to $L$. $(V$.) colombiensis, which has been isolated from humans (Kreutzer et al. 1991, Delgado et al. 1993), the public health importance of $L$. (V.) equatorensis remains to be determined. To date, it has only been isolated from arboreal mammals; no human infections with the parasite have been identified. Likewise, the sandfly vector (s) are unknown. However, the biological behaviour of $L$. (V.) equatorensis is indistinguishable from other members of the $L$. (V.) braziliensis complex, based on its virulence and development in laboratory animals. Inoculation of cultured promastigotes into the nose of hamster (Mesocricetus auratus) produced local swelling without metastasis; appearance of the lesions took 1-3 months, depending on the size of the inoculum (Grimaldi et al. 1992). Moreover, the restriction profile of the internal transcribed spacers of the rRNA gene showed a close pattern between $L$. (V.) equatorensis and $L$. (V.) colombiensis, but distinct from Endotrypanum, supporting the taxonomic status of the former parasite, and that the two Leishmania species represent a link between Endotrypanum and Leishmania.

Comparative studies will be needed to address the antiquity of this evolutionary link group and, in particular, whether or not it represents a branch point on the origin of neotropical leishmanias. It is worth noting that sloths, which have always been restricted to the American continent, are consid-
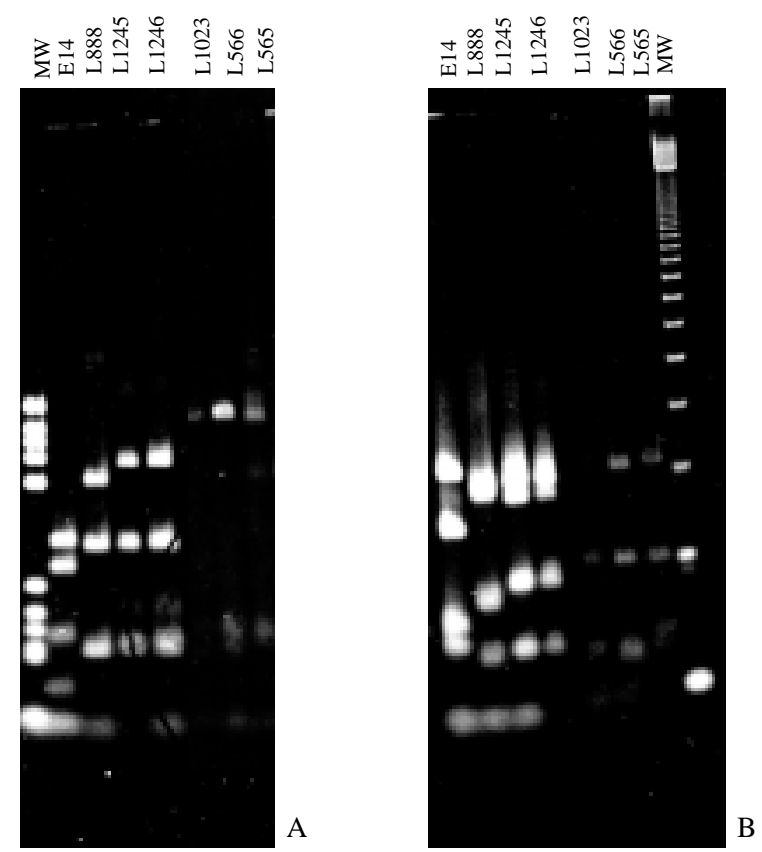

Fig. 3: restriction enzyme profile of the internal transcribed spacers of the rRNA genes for Leishmania species and Endotrypanum schaudinni. A. BstUI; B. Taq I. 
ered to have evolved from the basic Xenarthran armadillo-like stock some 60 million years ago during the Palaeocene period. These early mammals separated between the two and the three-toed groups of extant sloths later during the Miocene period. With this in mind, we feel that the neotropical leishmanias may well have evolved from a primitive endotrypanumal Miocene parasite line of South American sloths.

\section{REFERENCES}

Arias JR, Miles MA, Naiff RD, Póvoa MM, de Freitas RA, Biancardini CB, Castellon EG 1985. Flagellate infections of Brazilian sand flies (Diptera: Psychodidae): isolation in vitro and biochemical identification of Endotrypanum and Leishmania. Am J Trop Med Hyg 34: 1096-1108.

Christensen H, Herrer A 1976. Neotropical sandflies (Diptera:Psychodidae), invertebrate hosts of Endotrypanum schaudinni (Kinetoplastida). J Med Entomol 13: 299-303.

Christensen H, Herrer A 1979. Susceptability of sandflies (Diptera:Psychodidae) to trypanosomatidae from two-toed sloths (Edentata: Bradypodidae). J Med Entomol 16: 424-427.

Croan D, Ellis J 1996. Phylogenetic relationships between Leishmania, Viannia and Sauroleishmania inferred from comparison of a variable domain within the RNA polymerase I I largest subunit gene. Mol Biochem Parasitol 79: 97-102.

Croan DG, Morrison DA, Ellis JT 1997. Evolution of the genus Leishmania revealed by comparison of DNA and RNA polymerase gene sequences. $\mathrm{Mol}$ Biochem Parasitol 89: 149-159.

Cupolillo E, Grimaldi Jr G, Momen H 1994. A general classification of New World Leishmania using numerical zymotaxonomy. Am J Trop Med Hyg 50: 296-311.

Cupolillo E, Grimaldi Jr G, Momen H 1997. Genetic diversity among Leishmania (Viannia) parasites. Ann Trop Med Parasitol 91: 617-626.

Cupolillo E, Grimaldi Jr G, Momen H, Beverley SM 1995. Intergenic region typing (IRT): a rapid molecular approach to the characterization and evolution of Leishmania. Mol Biochem Parasitol 73: 145-155.

Deane LM 1961. Tripanosomatídeos de mamíferos da região Amazônica. I. Alguns flagelados encontrados no sangue de mamíferos silvestres do Estado do Pará. Rev Inst Med Trop São Paulo 3: 15-28.

Delgado O, Castes M, White Jr AC, Kreutzer RD 1993. Leishmania colombiensis in Venezuela. Am J Trop Med Hyg 48: 145-147.

Eresh S, de Brujin MHL, Mendoza-León JA, Barker DC 1995. Leishmania (Viannia) lainsoni occupies a unique niche within the subgenus Viannia. Trans $R$ Soc Trop Med Hyg 89: 231-236.

Fernandes AP, Nelson K, Beverley SM 1993. Evolution of nuclear ribosomal RNAs in kinetoplastid protozoa: Perspectives on the age and origins of parasitism. Proc Natl Acad Sci USA 90: 11608-11612.
Fernandes O, Bozza M, Pascale JM, Miranda AB, Lopes UG, Degrave WM 1996. An oligonucleotide probe derived from kDNA minirepeats is specific for Leishmania (Viannia). Mem Inst Oswlado Cruz 91: 279284.

Fernandes O, Pacheco RS, Momen H, Degrave W, Campbell DA 1995. Leishmania lainsoni: a peculiar Viannia species. Ann Trop Med Hyg 89: 81-82.

Floch H 1954. Leishmania tropica guyanensis $\mathrm{n}$.sp. agent de la leishmaniose tegumentarie de Guyanes et de l'Amerique Centrale. Arch Inst Pasteur de La Guyane Française et du Teritoire de L'Inni 15: 328.

Franco AMR, Machado GMC, Naiff RD, Moreira CFS, McMahon-Pratt D, Grimaldi Jr G 1997. Characterization of Endotrypanum parasites using specific monoclonal antibodies. Mem Inst Oswaldo Cruz 92: 63-68.

Franco AMR, Momen H, Naiffi RD, Moreira CFS, Deane MP, Grimaldi Jr G 1996. Enzyme polymorphism in Endotrypanum and numerical analysis of isoenzyme data. Parasitology 113: 39-48.

Grimaldi Jr G, Tesh RB 1993. Leishmaniases of the New World: current concepts and implications for future research. Clin Microbiol Rev 6: 230-250.

Grimaldi Jr G, Kreutzer RD, Hashigushi Y, Gomez EA, Mimory T, Tesh RB 1992. Description of Leishmania equatorensis sp.n. (Kinetoplastida: Trypanosomatidae), a new parasite infecting arboreal mammals in Ecuador. Mem Inst Oswaldo Cruz 87: 221228.

Grimaldi Jr G, Tesh RB, McMahon-Pratt D 1989. A review of the geographic distribution and epidemiology of Leishmaniasis in the New World. Am J Trop Med Hyg 41: 687-725.

Herrer A 1971. Leishmania hertigi sp. n. from the tropical porcupine, Coendou rothschildi Thomas. $J$ Parasitol 57: 626-629.

Kreutzer RD, Corredor A, Grimaldi Jr G, Grogl M, Rowton ED, Young DG, Morales A, McMahon-Pratt D, Guzman H, Tesh RB 1991. Characterization of Leishmania colombiensis sp.n. (Kinetoplastida: Trypanosomatidae), a new parasite infecting humans, animals, and phlebotomine sand flies in Colombia and Panama. Am J Trop Med Hyg 44: 662-675.

Kumar S, Tamura K, Nei M 1993. MEGA: Molecular evolutionary analysis, version 1.01 . The Pennsylvania State University, Philadelphia, PA.

Lainson R 1997. On Leishmania enriettii and other enigmatic Leishmania species of the neotropics. Mem Inst Oswaldo Cruz 92: 377-387.

Lainson R, Shaw JJ 1972. Leishmaniasis in the New World: taxonomic problems. Brit Med Bull 28: 4448.

Lainson R, Shaw JJ 1977. Leishmania of neotropical porcupines: Leishmania hertigi deanei nov. subsp. Acta Amazonica 7: 51-57.

Lainson R, Braga RR, De Souza AAA, Póvoa MM, Ishikawa EAY, Silveira FT 1989. Leishmania (Viannia) shawi sp. n., a parasite of monkeys, sloths and procyonids in Amazonian Brazil. Ann Parasitol Hum Сотр 64: 200-207.

Medina-Acosta E, Franco AMR, Jansen AM, Sampol 
M, Nevés N, Pontes-de-Carvalho L, Grimaldi Jr G, Nussenzweig V 1994. Trans-sialidase and sialidase activities discriminate between morphologically indistinguishable trypanosomatids. Eur J Biochem 225: 333-339.

Noyes HA, Arana BA, Chance ML, Maingon R 1997. The Leishmania hertigi (Kinetoplastida; Trypanosomatidae) complex and the lizard Leishmania: their classification and evidence for a neotropical origin of the Leishmania-Endotrypanum clade. J Euk Microbiol 44: 511-517.

Noyes HA, Camps AP, Chance ML 1996. Leishmania herreri (Kinetoplastida; Trypanosomatidae) is more closely related to Endotrypanum (Kinetoplastida; Trypanosomatidae) than to Leishmania. Mol Biochem Parasitol 80: 119-123.

Pacheco RS, Thomaz N, Momen H 1990. kDNA crosshybridization between Endotrypanum and peripylarian Leishmania. Trans R Soc Trop Med Hyg 84: 531.

Pipkin AC 1968. Domicillary reduviid bug and the epidemiology of Chagas' disease in Panama (Hemiptera: Reduviidae: Triatominae). J Med Entomol 5: 107-124. Rogers WO, Burnheim PF, Wirth DF 1988. Detection of Leishmania within sandflies by kinetoplast DNA hybridization. Am J Trop Med Hyg 39: 434-439.

Shaw JJ 1981. The behaviour of Endotrypanum schaudinni (Kinetoplastida: Trypanosomatidae) in three species of laboratory-bred neotropical sandflies (Diptera:Psychodidae) and its influence of the classification of the genus Leishmania, p. 232-241. In EU Canning, Parasitological Topics, Allen, Lawrence, KS.

Shaw JJ 1992. Endotrypanum, a unique intraerythrocytic flagellate of New World tree sloths. An evolutionary link or an evolutionary backwater? Ciên Cult 44: 107-116.

Thomaz-Soccol V, Lanotte G, Rioux J-A, Pratlong F, Martini-Dumas A, Serres E 1993. Monophyletic origin of the genus Leishmania Ross, 1903. Ann Parasitol Hum Comp 68: 107-108.

Travi BL, Zea A, D’Alessandro A 1989. Trypanosoma (Herpetosoma) leeuwenhoeki in Choloepus hoffmanni and Didelphis marsupialis of the pacific coast of Colombia. J Parasitol 75: 218-224.

Zeledon R, Ponce C, De Ponce E 1975. The isolation of Leishmania braziliensis from sloths in Costa Rica. Am J Trop Hyg 24: 706-707. 
